\title{
What Does Literature Say About the Determinants of Adoption of Agricultural Technologies by Smallholders Farmers?
}

\author{
Obayelu $\mathrm{AE}^{1 *}$, Ajayi $\mathrm{OD}^{2}$, Oluwalana EOA ${ }^{2}$ and Ogunmola $00^{1}$ \\ ${ }^{1}$ Department of Agricultural Economics and Farm Management, Federal University of Agriculture Abeokuta, Nigeria \\ ${ }^{2}$ Agricultural Media Resources and Extension Centre (AMREC), Federal University of Agriculture Abeokuta, Nigeria
}

Submission: February 23, 2017; Published: April 21, 2017

"Corresponding author: Obayelu AE, Department of Agricultural Economics and Farm Management, Federal University of Agriculture Abeokuta, Ogun State, Nigeria, Email: Obayelu@yahoo.com

\begin{abstract}
Understanding the determinants of adoption of agricultural technologies is essential in planning and executing technology related programmes for meeting the challenges of food production in developing countries. This study therefore extensively reviewed the various factors influencing adoption of agricultural technology among smallholder farmers. Results of the findings show that changes in technology adoption are associated with changes in the economic situation of the country, financial status of farm households and the net gain from adopting the technology, access to credit, access to information, travel cost, characteristics of the technology, scale of operation of the farmers, income, cultural norms and values, social network and human specific factors. The findings will be useful to technology developers, disseminators, and the end users (farmers). To increase the likelihood of adoption of the modern agricultural technologies by smallholders, policy makers should make credit accessible to farmers without gender discriminations, make information about the technology available via extension services, advice farmers to improve their educational level and carry the end users along while developing the technology.
\end{abstract}

Keywords: Adoption; Improved agricultural technology; Determinants; Smallholder farmers;

\section{Introduction}

Agricultural technology embodies a number of important characteristics that may influence adoption decisions [1]. The literature on agricultural technology adoption is enormous [2-4] and somewhat difficult to summarize closely [5-7]. Conventionally, analysis of agricultural technology adoption focused on imperfect information, risk, uncertainty, institutional constraints, human capital, input availability, and infrastructure as potential explanations for adoption decisions [8-10]. The recent literature now focuses on social networks and learning [11] to explain factor determining adoption behaviour of agricultural technology $[2,8,12]$. For instance, while some studies like Akudugu [13] have classified the determinants of adoption of agricultural technology into three categories namely; economic, social and institutional factors; Kebede et al. [14] broadly categorized the factors into: social, economic and physical factors; McNamara et al. [15] categorized the factors into: farmer characteristics, farm structure, institutional characteristics and managerial structure. Nowak [16] in his own case grouped them into informational, economic and ecological, while Wu \& Babcock [17] classified them under human capital, production, policy and natural resource characteristics.

This paper discusses the determinants of agricultural technology from the traditional, social, physical, and economic perspectives. The factors are: institutional factor, technological, economics, financial, physical, human, cultural and household specific factors.

\section{Materials and Methods}

The study used a structured literature review of publications in peer reviewed academic journals on adoption of agricultural technologies. By structured literature we mean a systematic, explicit, and reproducible design for identifying, evaluating, and interpreting the existing body of knowledge. 


\section{Results and Discussion}

\section{Characteristics of the agricultural technology}

Characteristic of a technology is a prerequisite of adopting it [18-20]. The degree to which a potential adopter can try something out on a small scale before adopting it completely is a major determinant of technology adoption [21]. In studying determinants of adopting Imazapyr-Resistant maize (IRM) technology in Western Kenya for instance, Mignouna et al. [22] stated that, the characteristic of the technology play a critical role in adoption decision process. They argued that farmers who perceive the technology as being consistent with their needs and compatible to their environment are likely to adopt such since they find it as a positive investment. Farmers' perception about the performance of the technologies significantly influences their decision to adopt them. Another examples is a study by Adesina \& Zinnah [18] that showed that farmers' perception of the characteristic of modern rice variety significantly influenced their decision to adopt it. A similar result was reported by Wandji et al. [23] when studying perception of farmers towards adoption of Aquaculture technology in Cameroon and that of Mwangi \& Kariuki [20] on factors determining adoption of new agricultural technology by smallholder farmers in developing countries. More recently, some economists and other social scientists have focused more explicitly on farmers' motivations, values, objectives and behavioural influences in the context of technology adoption [24].

\section{Economic factors}

A key determinant of the adoption of a new technology is the net gain to the farmer from adoption, inclusive of all costs of using the new technology [25]. High cost of agricultural technology has been reported hindrance to adoption agricultural technology [26]. This is supported by other previous studies such as Chi \& Yamada [27], Nkonya et al. [28] on determinants of technology adoption. For instance, the elimination of subsidies on prices of seed and fertilizers since the 1990s due to the World Banksponsored structural adjustment programs in sub-Saharan Africa has widened this constraint [6]. The study done by Makokha et al. [29] on determinants of fertilizer and manure in maize production Kiambu county, Kenya reported high cost of labor and other inputs, unavailability of demanded packages and untimely delivery as the main constraints to fertilizer adoption. Cost of hired labor was also reported by Ouma et al. [31] as one among other factors constraining adoption of fertilizer and hybrid seed in Embu county Kenya. Wekesa et al. [30] when analyzing determinants of adoption of improved maize variety in coastal lowlands of Kenya found high cost and unavailability of seeds as one of factors responsible for low rate of adoption. Off farm income has been shown to have a positive impact on technology adoption. This is because off-farm income acts as an important strategy for overcoming credit constraints faced by the rural households in many developing countries [32]. Off-farm income is reported to act as a substitute for borrowed capital in rural economies where credit markets are either missing or dysfunctional [33]. According to Diiro [33] off- farm income is expected to provide farmers with liquid capital for purchasing productivity enhancing inputs such as improved seed and fertilizers.

\section{Physical factors}

Physical factors such as the farm size play a critical role in adoption process of a new technology [20]. Many studies have reported a positive relation between farm size and adoption of agricultural technology [5,22,34]. Small farm size provides an incentive to adopt a technology especially in the case of an input-intensive innovation such as a labor-intensive or landsaving technology. Farmers with small land adopt land-saving technologies such as greenhouse technology, zero grazing among others as an alternative to increased agricultural production [35]. Some technologies are termed as scale-dependant because of the great importance of farm size in their adoption [36]. Farmers with large farm size are likely to adopt a new technology as they can afford to devote part of their land to try new technology unlike those with less farm size.

\section{Human factors}

Farmers are consumers of the products of agricultural research and their subjective preferences for characteristics of new agricultural technologies affect their adoption decisions [1]. Farmers are also important as sources of technology information and agents of technology transfer. The risk preferences of farmers are also important in influencing the technology adoption decision, especially if capital-intensive technology costs are irreversible [3]. When farmers assess the characteristics of new technologies and find them to match their preferences, they often give the technologies to other farmers to test and evaluate thereby setting into motion an endogenous process of technology diffusion.

\section{Access to information and social network}

Farmers need to know the existence of technology, its beneficial, and its usage for them to adopt it. Acquisition of information about a new technology is another factor that determines adoption of technology [37]. It enables farmers to learn the existence as well as the effective use of technology and this facilitates its adoption. Farmers will only adopt the technology they are aware of or have heard about it. Access to information reduces the uncertainty about a technology's performance hence may change individual's assessment from purely subjective to objective over time. Access to information may also result to dis-adoption of the technology. For instance, where experience within the general population about a specific technology is limited, more information induces negative attitudes towards its adoption, probably because more information exposes an even bigger information vacuum hence increasing the risk associated with it Bonabana- Wabbi [36]. It is therefore important to ensure the information is reliable, consistent and accurate.

Access to extension services helps to spread information about new agricultural technology leading to adoption. Farmers are usually informed about the existence as well as the effective use and benefit of new technology through extension agents. Extension 
agent acts as a link between the innovators (Researchers) of the technology and users of that technology. This helps to reduce transaction cost incurred when passing the information on the new technology to a large heterogeneous population of farmers [38]. Extension agents usually target specific farmers who are recognized as peers (farmers with whom a particular farmer interacts) exerting a direct or indirect influence on the whole population of farmers in their respective areas. Many authors have reported a positive relationship between extension services and technology adoption. A good example include; Adoption of Imazapyr-Resistant Maize Technologies (IRM) by Mignouna et al. [22]; Factors determining technology adoption among Nepalese [39]; Adoption of improved maize and land management in Uganda by Kuuma [40]; adoption of modern agricultural technologies in Ghana [13] just to mention a few. This is because exposing farmers to information based upon innovation-diffusion theory is expected to stimulate adoption. In fact, the influence of extension agents can counter balance the negative effect of lack of years of formal education in the overall decision to adopt some technologies [38].

Belonging to a social group enhances social capital allowing trust, idea and information exchange. Farmers within a social group learn the benefits and usage of a new technology from one another. Uaiene et al. [5] suggests that social network effects are important for individual decisions, and that, in the particular context of agricultural innovations, farmers share information and learn from each other. Studying the effect of community based organization in adoption of corm-paired banana technology in Uganda, Katungi and Akankwasa (41) found that farmers who participated more in community-based organizations were likely to engage in social learning about the technology hence raising their likelihood to adopt the technologies. Although many researchers have reported a positive influence of social group on technology adoption, social groups may also have a negative impact on technology adoption especially where free-riding behaviour exists. Bandiera \& Rasul [42] suggests that, learning externalities generate opposite effects, such that the more other people engage in experimentation with a new technology, the more beneficial it is to join in, but also the more beneficial it is to free-ride on the experimentation of others.

\section{Credit systems}

Access to credit is found to be very important factor influencing the adoption of agricultural technology by the smallholders [43]. Credit can facilitate farm households to purchase the needed agricultural inputs and enhance their capacity to effect longterm investment in their farms. Credit access in some countries where female-headed households are discriminated against by credit institutions, prevent women who are into agriculture from adopting yield-raising technologies. leading to.

\section{Household-specific factors}

Human capital of the farmer is assumed to have a significant influence on farmers' decision to adopt new technologies [20]. Most adoption studies have attempted to measure human capital through the farmer's education, age, gender, and household size $[44,45,43]$. Education of the farmer has been assumed to have a positive influence on farmers' decision to adopt new technology. Education level of a farmer increases his ability to obtain; process and use information relevant to adoption of a new technology $[46,47]$. For instance a study by Okunlola et al. [48] on adoption of new technologies by fish farmers and Ajewole [49] on adoption of organic fertilizers found that the level of education had a positive and significant influence on adoption of the technology. This is because higher education influences respondents' attitudes and thoughts making them more open, rational and able to analyze the benefits of the new technology [50]. This eases the introduction of a new innovation which ultimately affects the adoption process [51]. Interaction with extension services [52,53] and peer-group behaviour [54] positively impact farmers' technology adoption decisions.

\section{Travel cost}

Other parts of the social science literature emphasise the role of distance and geography in the adoption of agricultural technologies. In this case, any significant travel costs involved in the initial learning about a technology and subsequently establishing it might reduce the likelihood of that technology's adoption.

\section{Cultural differences}

Cultural differences in attitudes and unobservable characteristics play a role in the adoption process. Cultural traits enter into the agricultural technological adoption process through network formation, indirect effects such as imitation, peer effects, and norm-based diffusion. For instance, Lee [55] examined whether cultural traits affect the diffusion of agricultural technologies in developing countries using data collected in Ghana and found that farmers belonging to clans with higher proportion of adopters are more likely to adopt agricultural technology [56].

\section{Conclusion and Recommendations}

The essence of the review is to dig deep into the various factors affecting the adoption of agricultural technologies by smallholder farmers. The review had revealed a vast factors affecting smallholder farmers' decision to adopt agricultural technologies. Findings from this study had shown that adoption of agricultural technology depends on a range factors which include among others: human specific factors, social factor, cultural factor, economic factor, characteristics of the innovation itself, education levels, capital, income, farm size, access to information, utlilisation of social networks, beside the cost of the inputs. It is imperative for policy makers to ensure that a wider spectrum of smallholders are able to have access to credit in order to improve their adoption level of agricultural technology. Developers of new agricultural technology should try to understand the farmers need as well as their ability to adopt technology in order to develop technology that will suit them.

\section{References}


1. Adesina AA, Baidu-Forson J (1995) Farmers' perceptions and adoption of new agricultural technology: evidence from analysis in Burkina Faso and Guinea, West Africa. Agricultural Economics 13: 1-9.

2. Rogers E (2003) Diffusion of Innovations. ( $5^{\text {th }}$ edn), New York, USA.

3. Sunding D, Zilberman D (2001) The Agricultural Innovation Process: Research and Technology Adoption in a Changing Agricultural Sector. In: Gardner B, Rausser G (Eds.), Handbook of Agricultural Economics, Elsevier Science, Netherlands.

4. Feder G, Umali DL (1993) The Adoption of Agricultural Innovations: A Review, Technological. Forecasting and Social Change 43(1): 215-239.

5. Uaiene RN (2011) Determinants of Agricultural Technology Adoption in Mozambique. Paper presented at "Dialogue on Promoting Agricultural Growth in Mozambique" 21 July 2011 Hotel VIP, Maputo.

6. Muzari W, Gatsi W, Muvhunzi S (2012) The Impacts of Technology Adoption on Smallholder Agricultural Productivity in Sub-Saharan Africa: A Review. Journal of Sustainable Development 5(8): 69-77.

7. Ochienno JT (2014) Influence of Communication on Adoption of Agricultural Innovation: A Case of the System of Rice Intensification in MWEA Irrigation Scheme. Unpublished Master of Arts in Communication Studies thesis, School of Journalism at the University of Nairobi.

8. Feder G, Just RE, Zilberman D (1985) Adoption of Agricultural Innovations in Developing Countries: A Survey. Economic Development and Cultural Change 33(2): 255-298.

9. Foster AD, Rosenzweig MR (1995) Learning by Doing and Learning from Others: Human Capital and Technical Change in Agriculture. Journal of Political Economy 103(6): 1176-1209.

10. Kohli DS, Singh N (1995) The Green Revolution in Punjab, India: The Economics of Technological Change. Revised version of the paper presented at a conference on Agriculture of Punjab at the Southern Asian Institute, Columbia University, USA.

11. Maertens A, Barrett CB (2013) Measuring Social Networks' Effects on Agricultural Technology Adoption." American Journal of Agricultural Economics 95(2): 353-359.

12. Uaiene R, Arndt C, Masters W (2009) Determinants of Agricultural Technology Adoption in Mozambique. Discussion papers No. 67E, pp. 1-31.

13. Akudugu MA, Guo E, Dadzie SK (2012) Adoption of modern agricultural production technologies by farm households in Ghana: What factors influence their decisions? Journal of Biology, Agriculture and Healthcare 2(3): 1-13.

14. Kebede Y, Gunjal K, Coffin G (1990) Adoption of new technologies in Ethiopian agriculture: the case of Teguelet-Bulga District, Shoa Province. Agric Econ 4: 27-43.

15. McNamara KT, Wetzstein ME, Douce GK (1991) Factors affecting peanutproducer adoption of Integrated Pest Management. Review of Agricultural Economics 13(1): 129-139.

16. Nowak PJ (1987) The adoption of agricultural conservation technologies: economicand diffusion explanations. Rural Sociology 52(2): 208-220.

17. Wu JJ, Babcock BA (1998) The choice of tillage, rotation, and soil testing practices: economic and environmental implications. American Journal of Agricultural Economics 80(3): 494-511.

18. Adesina A, Zinnah M (1993) Technology characteristics, farmers' perceptions and adoption decisions: a Tobit model analysis in Sierra Leone. Agricultural Economics 9: 297-311.

19. Pannell DJ, Marshall GR, Barr N, Curtis A, Vanclay F (2006) Understanding and promoting adoption of conservation technologies by rural landholders. Australian Journal of Experimental Agriculture 46: 1407-1424.

20. Mwangi M, Kariuki S (2015) Factors Determining Adoption of New Agricultural Technology by Smallholder Farmers in Developing Countries. Journal of Economics and Sustainable Development 6(5): 208-216.

21. Doss CR (2003) Understanding Farm Level Technology Adoption: Lessons Learned from CIMMYT's Micro surveys in Eastern Africa. CIMMYT Economics Working Paper 03-07, Mexico, p. 1-27.

22. Mignouna B, Manyong M, Rusike J, Mutabazi S, Senkondo M (2011) Determinants of Adopting Imazapyr-Resistant Maize Technology and its Impact on Household Income in Western Kenya. Ag Bioforum 14(3): 158-163.

23. Wandji DN, Pouomogne V, Binam JN, Nouaga RY (2012) Farmer's Perception and Adoption of New Aquaculture Technologies in the Western Highlands of Cameroon. Tropicultura 30(3):180-184.

24. Rehman T, McKemey K, Yates CM, Cooke RJ, Garforth CJ, et al. (2007) Identifying and understanding factors influencing the uptake of new technologies on dairy farms in SW England using the theory of reasoned action. Agricultural Systems 94: 281-293.

25. Foster A, Rosenzweig M (2010) Microeconomics of Technology Adoption," Annual Review of Economics 2: 395-424.

26. Kinyangi AA (2014) Factors Influencing the Adoption of Agricultural Technology among Smallholder Farmers in Kakamega North SubCounty, Kenya. Unpublished Research Project Submitted In Partial Fulfilment of The Requirements for the Award of the Degree of Master of Arts in Project Planning and Management of The University of Nairobi.

27. Chi TTN, Yamada R (2002) Factors affecting farmers' adoption of technologies in farming system: A case study in OMon district, Can Tho province, Mekong Delta. Japan International Research Center for Agricultural Sciences 10: 94-100.

28. Nkonya E, Schroeder T, Norman D (1997) Factors Affecting Adoption of Improved Maize Seed and Fertilizer in Northern Tanzania. Journal of Agricultural Economics 48(1): 1-12.

29. Makokha S, Kimani S, Mwangi W, Verkuijl H, Musembi F (2001) Determinants of Fertilizer and Manure Use for Maize Production in Kiambu District, Kenya. CIMMYT (International Maize and Wheat Improvement Center) Mexico.

30. Ouma J, Murithi F, Mwangi W, Verkuijl H, Gethi M, et al. (2002) Adoption of Maize Seed and Fertilizer Technologies in Embu District, Kenya. CIMMYT(International Maize and Wheat Improvement Center), Mexico.Reardon T, Stamoulis K, Pingali P (2007) Rural Nonfarm Employment in Developing Countries in an era of Globalization. Agricultural Economics 37(1):173-183.

31. Diiro G (2013) Impact of Off-farm Income on Technology Adoption Intensity and Productivity: Evidence from Rural Maize Farmers in Uganda. International Food Policy Research Institute.

32. Ahmed S (2004) Factors and Constraints for Adopting New Agricultural Technology in Assam With Special Reference to Nalbari District: An Empirical Study: Journal of Contemporary Indian Policy.

33. Yaron D, Dinar A, Voet H (2000) Innovations on Family farms: The Nazareth Region in Israel. American Journal of Agricultural Economics 74(2): 361-370.

34. Bonabana-Wabbi J (2002) Assessing Factors Affecting Adoption of Agricultural Technologies: The Case of Integrated Pest Management (IPM) in Kumi District, Msc Thesis Eastern Uganda.

35. Nguluu SN, Ransom JK, Ariithi CCK, Muhammad L (1996) Adoption of Improved Maize Technology in Eastern Kenya Following a Community 
Based Farmer Training Project.

36. Genius M, Koundouri M, Nauges C, Tzouvelekas V (2010) Information Transmission in Irrigation Technology Adoption and Diffusion: Social Learning, Extension Services and Spatial Effects.

37. Karki B, Siegfried B (2004) Technology Adoption and Household Food Security; analyzing factors determining technology adoption and impact of project intervention: A case of smallholder peasants in Nepal: Conference Paper in The Deutscher Tropentag held on 5-7 October 2004. Humboldt-University, Berlin.

38. Kuuma SD (2005) The adoption and impact of improved maize and land management technologies in Uganda. Journal of Agricultural and Development Economics 2(1): 67-84.

39. Bandiera O, Rasul I (2002) Social Networks and Technology Adoption in Northern Mozambique. Discussion Paper Series.London, UK, Centre for Economic Policy Research CEPR.

40. Mohamed K, Temu A (2008) Access to credit and its effect on the adoption of agricultural technologies: The case of Zanzibar. African Review of Money Finance and Banking pp. 45-89.

41. Katungi E, AkankwasaK (2010) Community-based organizations and their effect on adoption of agricultural technologies in Uganda: a study of banana pest management technology. Acta Hort 879: 719-726.

42. Keelan C, Thorne F, Flanagan P, Newman C (2014) Predicted Willingness of Irish Farmers to Adopt GM Technology. The journal of Agro biotechnology management and Economics 12(3 \& 4): 1-8.

43. Lavison R (2013) Factors Influencing the Adoption of Organic Fertilizers in Vegetable Production in Accra, Msc Thesis, Accra Ghana.

44. Namara E, Weligamage P, Barker R (2003) Prospects for adopting system of rice intensification in Sri Lanka: A socioeconomic assessment. Research Report 75. International Water Management Institute, Colombo, Sri Lanka.

45. Okunlola O, Akinwalere B (2011) Adoption of new technologies by fish farmers in Akure, Ondo State. Nigeria Journal of Agricultural Technology 7(6): 1539-1548.
46. Ajewole OC (2010) Farmers' Response to Adoption of Commercially Available Organic Fertilizers in Oyo State, Nigeria. African Journal of Agricultural Research 5(18): 2497-2503.

47. Waller B, Hoy W, Henderson L, Stinner B, Welty C (1998) Matching innovation with potential users: A case study of potato IPM practices. Agric Ecosyst Environ 70: 203-215.

48. Adebiyi S, Okunlola J (2010) Factors affecting Adoption of Cocoa Rehabilitation Techniques in Oyo State of Nigeria. Proceedings The $18^{\text {th }}$ Annual Congress of the Nigerian Rural Sociological Association of Nigeria, FUTA, Akure, Nigeria.

49. Millar J (2010) The Role of Extension for Improving Natural Resource Management: the Australian Experience. In: Jennings J, Packham R, Woodside D (Eds.), Shaping Change: Natural Resource Management, Agriculture and the Role of Extension. Australasia-Pacific Extension Network (APEN), Australia, pp. 102-110.

50. Garforth C, Angell B, Archer J, Green K (2003) Fragmentation or creative diversity? Options in the provision of land management advisory services. Land Use Policy 20(4): 323-333.

51. Sauer J, Zilberman D (2010) Innovation Behaviour at Farm Level Selection and Identification, 114th EAAE Seminar Structural Change in Agriculture, Berlin, Germany.

52. Lee K (2011) The Role of Culture in Agricultural Technology Diffusion in Ghana. Unpublished MMSS Senior thesis, Department of Economics.

53. Karugia S, Baltenweck I, Waithaka M, Miano M, Nyikal R, et al. (2004) Perception of Technology and its Impact on Technology Uptake: The Case of Fodder Legume in Central Kenya Highlands. The Role of Social Scientists Proceedings of the Inaugural Symposium, 6 to 8 December 2004, Grand Regency Hotel, Nairobi, Kenya.

54. Loevinsohn M, Sumberg J, Diagne A (2012) Under what circumstances and conditions does adoption of technology result in increased agricultural productivity? Protocol. EPPI Centre, Social Science Research Unit, Institute of Education, University of London, London.

\section{Your next submission with Juniper Publishers will reach you the below assets}

- Quality Editorial service

- Swift Peer Review

- Reprints availability

- E-prints Service

- Manuscript Podcast for convenient understanding

- Global attainment for your research

- Manuscript accessibility in different formats

( Pdf, E-pub, Full Text, Audio)

- Unceasing customer service

Track the below URL for one-step submission

https://juniperpublishers.com/online-submission.php 